\title{
IDENTIDADE À DERIVA: UMA LEITURA DE BERKELEY EM BELLAGIO, DE JOÃO GILBERTO NOLL
}

\author{
IDENTITY TO THE DERIVA: A READING OF \\ BERKELEY IN BELLAGIO, BY JOÃO GILBERTO NOLL
}

\section{Glauciane Reis Teixeira}

Recebido em: 02 de maio de 2017

Aprovado em: 28 de junho de 2017

Sistema de Avaliação: Double Blind Review

RPR | a. 14 | v. 2 | p. 39-50 | jul./dez. 2017

\section{RESUMO}

A narrativa Berkeley em Bellagio, de João Gilberto Noll, publicada em 2002 e finalista do prêmio Portugal Telecom de 2003, apresenta como protagonista um escritor brasileiro, também chamado de João. Este, em virtude dos constantes trânsitos por territórios nacionais e internacionais, é assolado por um incômodo sentimento de deslocamento subjetivo que desencadeia recorrentes crises identitárias. Nesse sentido, o romance nolliano retrata com apuro a sensação de desamparo dos indivíduos contemporâneos, integrantes do universo líquido-moderno, que, perante um mundo cada vez mais globalizado e excludente, esforçam-se o tempo todo para encontrarem um espaço seguro onde possam desenvolver vínculos de pertencimento. Dessa maneira, o presente trabalho tem como intuito principal discutir sobre a problemática do descompasso identitário que inquieta o protagonista, abordando, primeiramente os motivos que o impulsionam a abandonar a cidade de Porto Alegre. Logo depois, detém-se a atenção sobre a sensação de estraneidade e a inadequação linguística que o afeta durante o tempo em que permanece tanto na Califórnia quanto na Itália. Enfim, debate-se como o retorno ao solo natal é capaz de, simultaneamente, reestabelecer o equilíbrio identitário e indicar uma oportunidade de fixação identitária.

Palavras-chave: Identidade. Deslocamento. Fixação.

\begin{abstract}
The novel Berkeley em Bellagio, João Gilberto Noll, published in 2002, has as protagonist a Brazilian writer, named João, whose transits carried out in different territories, national and international, are always accompanied by an unsettling sense of subjective displacement. Thus, the nolliano text is the helplessness of the contemporary subject, part of the liquid-modern context, struggling both to find a safe haven and to establish links of belonging in a globalized and excluding world. This study aims to make reflections on identity misfit problem that afflicts the protagonist. For this, first we will hold the attention about the motives that impelled to leave the home town. Then, we observe the feeling of astonishment and linguistic inadequacy experienced by him during his stay in California and Italy; where the desire of contact, with the desire to transcend the limits of sexual practices, greater than the obstacles related to the non-language skills, gives a grounded socialization in the silence of touch and body experimentation. Finally, we discuss how the return to the city of Porto Alegre points to a possibility of fixing identity.
\end{abstract}

Keywords: Identity. Displacement. Fixation.

\footnotetext{
${ }^{1}$ Doutora em Letras pela Universidade Federal do Rio Grande do Sul (Porto Alegre/Brasil). Professora na Universidade Regional Integrada do Alto Uruguai e das Missões (Erechim/Brasil). E-mail: glauciane.reis@ yahoo.com.br.
} 
O homem vive desabrigado. Ele não tem mais lugar próprio onde se sinta 'em casa' [...] Não há mais casa em que ele possa alojar sua ideia de homem nem sua própria pessoa, desalojada em toda parte.

(Pierre Ouellet).

\section{CONSIDERAÇÕES INICIAIS}

Migrações, exílios, intercâmbios, viagens e outras diferentes configurações dos deslocamentos humanos configuram-se como um eixo temático em torno do qual giram grande parcela das narrativas brasileiras produzidas durante este início de século. É evidente que arquétipos de viajantes e/ou estrangeiros fazem parte do imaginário cultural do Ocidente, basta lembrarmo-nos de Ulisses, Jasão, Jesus ou Loth. No entanto, a literatura brasileira contemporânea coloca em destaque a representação de sujeitos sem rumo, desprovidos de certezas, destituídos de objetivos, sendo que "o sem-sentido de seu percurso [é, muitas vezes] reflexo do sem-sentido de sua existência" (DALCASTAGNÈ, 2012, p.116). Não obstante, vários desses seres ficcionais ocupam o espaço de modo contraditório, ou seja, ao mesmo tempo em que podem ocupar qualquer lugar são incapazes de sentirem-se confortáveis em tais ambientes, visto que, em contraponto com os clássicos heróis épicos, eles não dispõem mais do espaço apaziguador para onde possam regressar, a fim de recuperarem sua antiga vida.

Vinculada a essa tendência literária encontra-se a prosa produzida por João Gilberto Noll, cujos protagonistas sempre estão à deriva, sofrendo com as identidades fragmentadas, sentindo-se estrangeiras em todo meio pelo qual passam. Os textos nollianos, tal qual uma recorrência, como chama atenção Renato Cordeiro Gomes (2010), dramatizam personagens que cruzam fronteiras territoriais, vivendo a imediaticidade do trânsito, de maneira que "as viagens quase sempre são esvaziadas, corroendo a carga semântica que esse motivo carrega da tradição narrativa. Elas perdem o caráter formativo; o componente pedagógico cede lugar ao performático". Em virtude disso, Noll é considerado, pelo pesquisador Karl Erick Schøllhammer (2010, p.32), como "o intérprete mais original do sentimento pós-moderno de perda de sentido e de referência. Sua narrativa se move sem um centro, não ancorada num narrador autoconsciente".

A narrativa Berkeley em Bellagio, publicada em 2002 e finalista do prêmio Portugal Telecom de 2003, conserva esse mesmo viés temático de representação. O campus da Universidade de Berkeley, as montanhas em torno do lago di Como em Bellagio e as ruas alvoroçadas de Porto Alegre são os espaços por onde transita o protagonista, um escritor brasileiro chamado João, geralmente acompanhado de um inquietante sentimento de desajuste. A narrativa representa o desamparo do sujeito, integrante do contexto líquido-moderno, que se esforça tanto para encontrar um porto seguro quanto para estabelecer vínculos de pertencimento em um mundo globalizado e excludente, por isso "se desloca para [se] manter fixo" (NOLL, 2002, p.36).

A trama ficcional vertiginosa é conduzida pelo narrador-protagonista que oscila seu discurso, ou seja, a narração é elaborada ora por uma voz em terceira pessoa que se refere a si mesmo como outro, ora por uma voz em primeira pessoa, como fica perceptível no seguinte trecho:

Quando ele chegou aos Estados Unidos, tinha menos de cem dólares. A chefe do Departamento de Espanhol e Português em Berkeley $o$ esperava no aeroporto, sorrindo meio culpada por tantas atribulações que o consulado americano tinha me causado [...] (NOLL, 2002, p.16 grifos nossos). 
O texto, estruturado em um só parágrafo, intercala de forma não linear as lembranças imaginadas e as reais de João. Este, em síntese, passa uma temporada na Universidade da Califórnia, em Berkeley, ministrando aulas de Cultura Brasileira como professor visitante. Depois, a convite de uma fundação norte-americana situada em Bellagio, viaja para a Europa, com o objetivo de elaborar um romance em uma residência de intelectuais. Regressa, posteriormente, a sua cidade natal, Porto Alegre. A temporalidade é obscura e vaga, visto que os marcadores que permitiriam determinar um intervalo exato são muito escassos. Não podemos afirmar, com precisão, se o personagem esteve por alguns meses ou por anos no mesmo lugar.

Inadaptado ao mundo em torno de si, João tem dificuldade de diferenciar os espaços, sendo que nem sempre difere se está de chegada ou partida: "lhe acendeu a dúvida se estava ali chegando do Brasil, ou, ao contrário, se já estava voltando ao Sul do planeta" (NOLL, 2002, p.10). Ao longo das travessias, ele pouco distingue a passagem temporal, posto que viaja para ficar por um período curto e, somente no retorno, percebe que se manteve distante por vários anos: "Passou-se bem mais tempo que eu contava. Eu já nem lembrava. Fui para ficar um ano, sei lá, dois, o certo é que fiquei o tempo necessário para que Léo se envolvesse com a norueguesa e com ela procriasse" (NOLL, 202, p.86). Ademais, recusa-se a estabelecer um papel sexual fixo, relacionando-se tanto com homens quanto com uma mulher, sem nunca se autorreferenciar como homossexual ou bissexual. Não obstante, o protagonista é assolado por um desconforto identitário latente que se intensifica pelo fato de ele não falar a língua inglesa, dominante nos solos estrangeiros pelos quais se desloca.

Nesse sentido, o romance nolliano retrata com apuro a sensação de desamparo dos indivíduos contemporâneos, integrantes do universo líquido-moderno, que, perante um mundo cada vez mais globalizado e excludente, esforçam-se o tempo todo para encontrarem um espaço seguro onde possam desenvolver vínculos de pertencimento. Dessa maneira, o presente trabalho tem como intuito principal discutir sobre a problemática do descompasso identitário que inquieta o protagonista, abordando, primeiramente os motivos que o impulsionam a abandonar a cidade de Porto Alegre. Logo depois, detém-se a atenção sobre a sensação de estraneidade e a inadequação linguística que o afeta durante o tempo em que permanece tanto na Califórnia quanto na Itália. Enfim, debate-se como o retorno ao solo natal é capaz de, simultaneamente, reestabelecer o equilíbrio identitário e indicar uma oportunidade de fixação das raízes culturais.

\section{TRÂNSITO: A FUGA DA PRECARIEDADE}

Transitar de um espaço ao outro, distanciar-se do lugar que propicia segurança é sempre uma experiência que desencadeia rupturas, pois quem se entrega à travessia permanece situado entre um estranho sentimento de nostalgia e de privação. Com isso, o deslocamento provoca uma instabilidade nos limites do eu, haja vista que, como argumenta a estudiosa Maria Bernadette Porto (2010, p.74), "deslocar-se é desvenciliar-se das certezas identitárias, é ousar deixar a previsibilidade". O indivíduo que parte, mesmo que seja por um tempo determinado, é obrigado a se afastar da grande parte dos elementos que o identificam e o enraízam: a casa, o contato direto com os amigos, a paisagem, os costumes, enfim, os signos indicadores do pertencimento dele a um espaço e por extensão a um grupo. O sujeito que sai de sua terra natal passa a ser o elemento estrangeiro em um território também estrangeiro. Nesse novo ambiente, surge a necessidade de (re)inventar-se, recomeçar um novo processo de identificação, estabelecer novos elos de pertencimento frente à sensação de não pertencimento.

Estar em movimento, no universo líquido-moderno, mais do que uma vontade própria, uma possibilidade ou um direito, torna-se uma verdadeira imposição. Os habitantes do mundo globalizado 
contemporâneo são continuamente pressionados a se deslocarem, já que a mudança se apresenta como uma exigência que beira uma obsessão: quem permanece parado/fixo está condenado à obsolescência. Zygmunt Bauman (2005), ao discorrer sobre o tempo presente, explica que estamos em deslocamento mesmo que estejamos fisicamente imóveis. À proporção que nos deparamos com a instabilidade, a incerteza e a pulsão pelo movimento, somos induzidos a transformar nossas identidades sociais, profissionais, sexuais, religiosas. Em consequência, alteramos os vínculos de pertencimento, e isso nos estimula a buscar relações fugazes e transitórias, fazendo com que soframos as angústias inerentes a essa condição. Logo, as velhas identidades, conformadas através de um "eu" homogêneo e coerente, convertem-se, nas palavras de Stuart Hall (2004, p.13), em "celebrações móveis", porque os sujeitos passam a assumir diferentes identidades, nos diversos âmbitos da vida, que muitas vezes são contraditórias entre si.

A necessidade de estar em mobilidade constante desencadeia, mais do que a impressão de estar fora de casa, um desconfortável sentimento de estar fora de lugar, gerado pelo mal-estar oriundo da ambígua posição de ocupar um espaço do qual não se pertence. Por extensão, o indivíduo busca experimentar o doce gosto da integração plena, porém apenas consegue sentir o amargo sabor da inadaptação, uma vez que qualquer espaço que ocupe sempre haverá "alguma coisa a explicar, desculpar, esconder ou, pelo contrário, corajosamente ostentar, negociar, oferecer e barganhar. Há diferenças a serem atenuadas ou desculpadas ou, pelo contrário, ressaltadas e tornadas mais claras" (BAUMAN, 2005, p.19).

Maria Zilda Cury (2013), por sua vez, menciona a precariedade como um dos efeitos maléficos produzidos pelos mecanismos próprios da globalização, visto que "o capitalismo avançado conferiu às condições sociais no mundo contemporâneo um caráter inequívoco de incerteza, imprimindo uma marca de precariedade" (CURY, 2013, p.33) que acomete não apenas as massas marginalizadas de países em desenvolvimento, mas também grupos de países sob o estado de bem-estar social que enfrentam crises econômicas. Propagou-se, portanto, a fragilidade da habitação e do trabalho, aumentando os bolsões de pobreza no mundo todo. Ademais, como produto da globalização, acompanha-se cada vez mais a intensificação das "diásporas contemporâneas, desterritorializando contingentes de pessoas premiadas pelos conflitos, pela perseguição religiosa, pela carência social e pela fome" (CURY, 2013, p.34).

Para estes que são impulsionados a se movimentarem pela necessidade de sobrevivência, a globalização gera angústia em virtude das adversidades de inclusão oriundas das barreiras impostas ao emprego, potencializando, assim, a marginalização. A globalização, um fenômeno que modificou de forma irreversível "as estruturas estatais, as condições de trabalho, as relações entre os Estados, a subjetividade coletiva, a produção cultural, a vida cotidiana e as relações entre o eu e o outro" (BAUMAN, 2005, p.11), altera as questões de identidade na mesma medida em que afeta a noção de pertencimento dos indivíduos.

O protagonista de Berkeley em Bellagio metaforiza o drama do homem contemporâneo pressionado a se movimentar, seduzido pelas possibilidades ofertadas pelo território estrangeiro. João é um homem de meia idade incapaz de conseguir extrair de seu solo natal, a cidade de Porto Alegre, os nutrientes necessários para manter uma subsistência adequada. A extrema precariedade que o afeta no próprio habitat natural é expressa logo nas primeiras linhas da narrativa, quando o narrador, já em Berkeley, tece questionamentos sobre os benefícios de um futuro retorno: 
Saberia voltar atrás? Não se arrependeria ao ter de mendigar de novo em seu país de origem? Fingir que não pedia pedindo refeições, ou a casa de veraneio de um amigo em pleno inverno para escrever um novo livro [...] [voltaria] para aquela falta de trabalho ou de aceno de qualquer coisa que lhe restituísse a prática do convívio em volta de uma refeição [...] (NOLL, 2002, p.9-10).

A posição de completa penúria é assumida pelo narrador-protagonista, que se apresenta quase como um miserável pedinte. Sua identidade, na capital gaúcha, é constituída sob o signo da negatividade: desprovido de "altas formações acadêmicas" (NOLL, 2002, p.16), "sem ter onde cair morto em sua própria terra" (NOLL, 2002, p.28), "desempregado, sem endereço fixo" (NOLL, 2002, p.16). Tudo isso o leva a acreditar ser "alguém que nada faz, que nada tem, nem menos o seu próprio corpo..." (NOLL, 2002, p.52).

É conveniente mencionarmos que o trabalho é um dos elementos mais caros para os processos de identificação dos sujeitos. O ordenado recebido permite manter ou não o status social; assim, o vínculo empregatício é o responsável por delinear parte da identidade dos indivíduos, em especial, a representação econômica. Nesse sentido, estar excluído do universo trabalhista nos tempos atuais, afigura-se como uma condição equivalente a de "ser recusado, marcado como supérfluo, inútil, inábil para o trabalho e condenado a permanecer 'economicamente inativo'. Ser excluído do trabalho significa ser eliminável, classificado como descarte [...]” (BAUMAN, 2009, p.23). Portanto, João, ocupando a posição de desempregado, tendo que mendigar por uma refeição aos amigos, carece de um elo trabalhista que o prenda à cidade de Porto Alegre.

Essa precariedade, justamente, funcionará como um empecilho, o qual retardará o ingresso do protagonista no país considerado a potência máxima do mundo desenvolvido. João revela que seu passaporte voltara sem o visto por muitas vezes, provavelmente em razão da falta de um trabalho ou de um endereço certo. Para provar que o seu trânsito não escondia uma tentativa de imigração, ele

Fez três vezes em vinte dias Porto Alegre-São Paulo-Porto Alegre de ônibus rumo ao consulado americano, dinheiro emprestado, levando recortes de jornais comentando seu período de escritor residente em Berkeley, agora como futuro professor convidado, dando cursos sobre Clarice, Graciliano, Raduan, Caio, Mirisola e alguns outros, mais alguns cursos sobre MPB [...] (NOLL, 2002, p.14).

É relevante destacar que, no Brasil, apesar de ter conseguido um determinado reconhecimento, já que é chamado por uma instituição norte-americana, o narrador-protagonista precisa levar para o consulado outros documentos comprobatórios, como uma espécie de garantia de boa procedência. Sobre essa passagem, ainda chamamos a atenção para o fato de que os territórios estrangeiros ofertam algo que a terra natal lhe nega: o trabalho. João tem a oportunidade de passar da invisibilidade de um desempregado para a posição de realce de "escritor residente" e "professor visitante", e, desse modo, estabelecer vínculos positivos de um novo pertencimento, enfim, desfrutar e exercitar uma nova faceta identitária.

João representa o típico indivíduo do contexto líquido-moderno que se entrega às possibilidades ofertadas pela vida e pelo mundo globalizado. Ele poderia ter desistido diante de tantas negativas e da falta de recursos próprios para pagar as despesas de viagem até o consulado; todavia, em vez de resignarse pela má sorte, o personagem persiste, crê na partida como algo certo: “eu vou, eu vou embora para um lugar que ainda não foi feito e que me espera entre a sombra da torre do convento ao norte e a velha figueira ao sul há mais de século sem se opor a nada" (NOLL, 2002, p.16). O escritor desempregado vislumbra as novas portas abertas, embora desconhecidas, joga-se em busca de uma vida melhor por meio de um status mais elevado em Berkeley e em Bellagio. A liberdade de alterar qualquer aspecto da 
identidade individual, conforme Bauman (2005), é uma dádiva disponível para a maioria dos sujeitos, pois existem diversas alternativas de identidades que podem ser acionadas. O personagem de Noll não hesita, agarra-se aos convites que lhe são feitos, até porque, além da inexistência de um trabalho há, também, a falta de outros dois elos que o prenderiam à terra.

Um dos elos que estariam ausentes na vida do protagonista diz respeito ao laço afetivo. A família, os amigos, os parceiros amorosos constituem um vínculo emocional forte, que colabora na conformação da identidade dos indivíduos, ao mesmo tempo em que os enraíza a determinados espaços. Em Porto Alegre, ele vivia solitariamente, somente tinha "alguns amigos, um ou dois parentes" (NOLL, 2002, p.73) e um relacionamento sexual com Léo. O rompimento dessa relação homoafetiva no romance é nebulosa, em virtude de o narrador-protagonista não ter certeza do realmente aconteceu, embora julgue "ter enterrado [Léo] para sempre como parceiro" (NOLL, 2002, p.85). João menciona que esse companheiro era alguém de suma importância em sua vida, porque "lhe emprestava um pouco da prática da vida" (NOLL, 2002, p.20), ou seja, mostrava quem era ou não confiável, o que diminuía o receio de não ser aceito e, principalmente, por conseguir para o escritor o que ele próprio não conseguia para si. No entanto, aparentemente, o envolvimento tem um fim:

[...] eles se sentiam impossibilitados de resistir à tirania da rotina os apartando um do outro até o ponto em que voltar para casa tornava-se um martírio, mesmo que na hora anterior ao desenlace (e houve?) os dois tenham ido para a cama em pleno dia, ali ejaculando juntos sem se olharem, sem se abraçarem, sem se tocarem, apenas para selar com o jorro amarelado da história deles dois, mais nada (NOLL, 2002, p.20).

Se aconteceu ou não um desenlace planejado, não sabemos. Porém, a história foi encerrada sem necessitar de nenhuma palavra ou toque de despedida. Findo o relacionamento, não há ninguém que, afetivamente, segure-o na cidade. Ele está livre para transitar.

O outro vínculo em déficit refere-se à memória. Antes de viajar, não sabemos exatamente quando, João sofrera um acidente doméstico: caíra no banheiro e batera a cabeça. A queda deixara, como sequela, o protagonista "assim meio esquecido" (NOLL, 2002, p.9), sua memória fora afetada de tal maneira que passara a sofrer crises de amnésia e lapsos mnemônicos. Esse acidente se configura como um emblema da crise que o assola, definitivamente ele está desprovido de quase todos os elos de pertencimento, inclusive da memória que possibilita narrar a si próprio e a sua trajetória histórica existencial. Como consequência, essa sequela o conduz a um processo de tentativa de reconstrução, de modo simultâneo, da memória e da identidade em solo estrangeiro.

Considerando o exposto até o momento, não é difícil compreendermos a persistência do personagem em conseguir o visto e o seu anseio em deslocar-se, haja vista que não vislumbramos vínculos positivos ou sólidos que o conectem a sua cidade natal. Os indivíduos apenas percebem as coisas e as avaliam com atenção quando estas "se desvanecem, fracassam, começam a se comportar estranhamente ou as decepcionam de alguma forma" (BAUMAN, 2005, p.23). Dessa forma, a vida precária marcada pela escassez de referenciais pessoais, as inexistentes oportunidades de trabalho oferecidas por Porto Alegre, o rompimento do laço com o homem que lhe servia de esteio, bem como os lapsos de memória e a possibilidade de ocupar um status elevado ao longo da estada no exterior constituem os ingredientes básicos para a mobilidade geográfica do protagonista de Noll. É, exatamente, um conjunto de influxos externos e internos que pressionam os sujeitos à travessia de uma fronteira em direção ao exterior. A respeito dessa perspectiva, Júlia Kristeva (1994, p.13) argumenta que o estrangeiro, antes da partida, ocupa a desconfortável posição entre "A rejeição de um lado e o inacessível de outro: se tiver forças para não sucumbir a isso, resta procurar um caminho". O caminho escolhido por João é o trânsito por territórios norte-americanos e italianos. 


\section{ESTRANEIDADE, ENTRAVE LINGUÍSTICO E PULSÃO SEXUAL: REFLEXOS DA IDENTIDADE À DERIVA}

Se João não se integra de modo pleno em Porto Alegre, tampouco consegue se ajustar nos espaços estrangeiros pelos quais transita. O sentimento de inadequação o acompanha já que, estranhamente, ele não se desvencilha de todas as amarras identitárias; uma se mantém, afigurando-se como o vínculo de pertencimento mais forte: a língua portuguesa. A narrativa começa, precisamente, colocando em relevo essa problemática: "Ele não falava inglês. Quando deu seu primeiro passeio pelo campus de Berkeley, viu não estar motivado. [...] Ele não falava inglês e se perguntava se algum dia arranjaria disposição para aprender mais uma língua além do seu português viciado" (NOLL, 2002, p.9).

$\mathrm{Na}$ Universidade da Califórnia, o deslocamento subjetivo do protagonista não chega a ser tão traumático. Quer dizer, durante as aulas de Cultura Brasileira, a língua inglesa é totalmente dispensável, porque João comunica-se em português com os alunos. Com essa disciplina, o professor assume o papel de elemento estrangeiro que apresenta imagens (através de filmes brasileiros como São Bernardo, A hora da estrela, A ilha das flores) de uma realidade sociocultural distante dos universitários - os quais, por sua vez, são estrangeiros para aquele contexto exibido. O contato com o outro é travado linguisticamente sem desconforto, há um jogo de aproximação estimulado pela diferença. Apesar disso, o protagonista se questionava a quem realmente interessava aquele conteúdo programático, chegando a perceber o falso entusiasmo que quase todos representavam:

Simulavam então diante de mim um interesse mais que suficiente para lhes render êxitos a mais em seus currículos de agentes não importa de que instituição, secreta ou não, agentes de bandeira que fingiam amar sobre todas as coisas, mesmo que tentassem às vezes molestá-la em minha presença, afetando a visão para me mimar" (NOLL, 2002, p.19).

Na Itália, essa posição altera-se de modo drástico, intensificando o sentimento de mal-estar do protagonista por não se ajustar ao meio. Como "escritor residente", em Bellagio, João permanece hospedado no palácio denominado "Catedral" - situado na Villa Solti, à beira do lago di Como -, o qual é uma fundação mantida pela Universidade de Berkeley. Tal palácio é representado como o espaço da elite, em especial, da elite norte-americana, reunindo intelectuais pertencentes a um tipo de "alto clero", provenientes, em sua grande parte, dos Estados Unidos e da Califórnia. Assim, a fundação seria o território do poder, tanto que o narrador-protagonista chega a listar os poucos artistas que não integravam o grande grupo dos privilegiados: "[...] no mais, no momento, a chilena da ONU, uma poeta tcheca, três músicos coreanos, um filipino, não muito mais que isso" (NOLL, 2002, p.29).

Esse ambiente, que mais se assemelha a uma ilha da elite norte-americana, inserida em terras italianas, tem como traço característico a estraneidade. A fundação é o outro para o próprio lugar que ocupa geograficamente, uma vez que o uso da língua oficial italiana é restrito aos empregados do palácio, de forma que os não falantes da língua inglesa carecem de voz. Por conseguinte, o português não passa de um código quase que enigmático e periférico. Em meio a essa hegemonia do inglês, o "escritor residente" sente o peso do desvio linguístico, o que potencializa a sensação de desajuste.

Em frente ao outro, o protagonista é obrigado a não só expor, como também assumir a si mesmo, a sua alteridade. Em outras palavras, é em Bellagio que João se percebe estranho para ele próprio, passando a se questionar sobre quem realmente era: "eu [talvez] não seja um outro que de fato sou, um estrangeiro de mim mesmo entre norte-americanos (embora em solo italiano)?[...] não fiz umas perguntas, tchê?" (NOLL, 2002, p.36). A concepção de estrangeiro que Noll coloca em jogo a partir dessa reflexão ultrapassa uma situação transitória, na qual os indivíduos se submetem quando precisam 
se ausentar da terra natal. A problemática transcende tal ideário para se redimensionar e englobar a própria estrutura do sujeito, visto que, como defende Kristeva (1994, p.9), "o estrangeiro habita em nós: ele é a face oculta da nossa identidade, o espaço que arruína a nossa morada, o tempo em que se afundam o entendimento e a simpatia".

O outro que João, conscientemente, sente que o habita já estava presente dentro dele antes mesmo de sair do Brasil, quando era incapaz de ajustar-se de maneira plena em Porto Alegre. Ademais, o escritor sofria de um "mutismo feito o mais total disléxico em língua inglesa ou em qualquer outra" (NOLL, 2002, p.24), as palavras pareciam sempre insuficientes para expressar a verdadeira carga subjetiva. Mesmo em língua portuguesa, tinha a sensação de que os lexemas pronunciados se distanciavam do caos a que pretendia aludir, em virtude disso acabava se isolando "numa masmorra anterior à lógica da frase" (NOLL, 2002, p.25). Conjuntura que é potencializada durante a sua estada no exterior, sendo que, na Califórnia e na Itália, ele se aprisiona no "cárcere do idioma do qual não pretendia sair" (NOLL, 2002, p.26).

João é uma personagem em busca da palavra perfeita para se relacionar e, em não a encontrando em nenhuma língua, entrega-se a outra forma de comunicação e de encontro com o outro. O desejo de contato, junto ao anseio de extrapolar os limites das práticas sexuais, maiores que os entraves linguísticos, origina uma socialização em território estrangeiro, alicerçada no silêncio do toque e da experimentação corpórea. O sexo emerge sob a forma de um "ritual de poucas palavras, [...] [afinal] para que palavras se [o] silêncio entrecortado de respirações fora do ritmo é o suficiente" (NOLL, 2002, p.60) para que os sujeitos produzam sentidos. A verborragia é completamente supérflua perante a atração dos corpos sedentos de prazer, "se falar naquele instante [do toque nos genitais] pressupunha, como parecia uma animação até a extremidade de algum entendimento, se falar fosse sinônimo disso tudo, ah, eles os dois não queriam mais" (NOLL, 2002, p.15-16).

A propósito, os trânsitos de João pelo exterior são marcados por contatos afetivos aleatórios e fugazes. O protagonista envolve-se sexualmente tanto com uma antropóloga brasileira, Maria, quanto com homens de diferentes idades, nacionalidade e status sociais. Em qualquer ambiente, desde um quarto fechado até espaços abertos e públicos (como atrás da cortina da sala de refeição), o corpo está sempre pronto para ter seus desejos saciados. Aliás, a sexualidade exacerbada é um traço característico do estrangeiro. Como menciona Kristeva (1994, p.37 grifos nossos), o movimento de separação do território original e o assentamento em "outro lugar é uma audácia acompanhada de um frenesi sexual: sem mais proibições, tudo é possível”.

Os rápidos contatos sexuais de João também podem ser vistos como emblemas dos relacionamentos na era líquida-moderna, os quais, motivados pela conduta consumista, "tendem a ser flutuantes, frágeis e flexíveis" (BAUMAN, 2004, p.41). Entretanto, quantidade não repercute em qualidade, e, os efêmeros envolvimentos afetivos travados em Berkeley e em Bellagio acabam apenas amplificando o sentimento de solidão que o narrador-protagonista experimenta em solo estrangeiro. $\mathrm{O}$ "escritor residente" passa a nutrir um intenso anseio pela constituição de laços duradouros, como fica explícito em trechos como estes: "E choraria mais por toda a vida por esses desencontros quase que diários, até que uma noite eu pudesse ter alguém ao meu lado, nós dois deitados sobre os lençóis recémlavados, ainda tépidos pelo ferro de passar, sem nada aspirar além de um sono" (NOLL, 2002, p.48) e "de que adianta dormir em minha cama se quando acordo não tem ninguém pra quem dizer bom-dia, até amanhã, talvez?” (NOLL, 2002, p.79).

Diferentemente de outras personagens nollianas, o protagonista de Berkeley em Bellagio ambiciona uma rotina que amenize sua condição de vulnerabilidade, quer alguém que permaneça consigo por um relativo tempo e almeja, nessa perspectiva, criar um vínculo de pertencimento. Tal 
desejo também é um fator que contribui com o aumento da sensação de deslocamento dele para com o espaço que ocupa e a identidade que desfruta.

João, de modo paulatino, reconhece e assume para si mesmo o outro que lhe habitava a existência. Contudo, a aceitação tem um custo alto: o esquecimento do português. Em determinada altura da narrativa, ele passa a dominar, subitamente, as estruturas linguísticas inglesas:

Virei-me, olhei para a "Catedral" americana, vi que ela continuava ali com toda a sua pompa, não importa, o que importava de fato naquele instante era que eu já pensava em inglês, se perguntassem de onde tinha vindo essa repentina fluência nessa língua, um cínico que me ouvia cá dentro responderia que eu fora iluminado durante o meu longo, longo sono pelo Espírito Santo - Holly Ghost, é lógico, tudo em inglês (NOLL, 2002, p.55).

É surpreendente que esse repentino domínio do inglês soterre, pontualmente, o principal vínculo positivo de pertencimento ao Brasil que ainda resistia intacto. Como se estivesse sido abalado por uma amnésia linguística, nenhum esforço que João faça é dotado de propriedades suficientes capazes de restituir o idioma materno e as lembranças relacionadas a terra natal:

Eu me debato agora, corro pelo quarto como se numa dança afro, bato com a cabeça na parede porque só consigo pensar em inglês, o que treino para dizer no imaginário para alguém já sai corrido nessa língua como se o idioma tivesse pressa de chegar para vencer meu português, matar o meu ofício, minha ocupação - me deportar para o primeiro voo de Milão para São Paulo, para eu descer em Porto Alegre como um gringo desvalido, sem saber o que fazer de mim numa cidade que eu já não reconheço, não sei meu endereço, não lembro de parente, [...] o inglês é a minha língua de repente, não poderei mais sobreviver com meu gasto português já esquecido, [...] (NOLL, 2002, p.62-63).

Embora não seja possível confiarmos cegamente na descrição desse acontecimento súbito, dada a narrativa ser elaborada pela voz de um narrador com grandes lapsos de memória, é aceitável concebermos que a aquisição do inglês e o esquecimento do português funciona como um mecanismo de tornar-se outro. Quando João, anteriormente, indagara-se a respeito de ser um estrangeiro para si próprio, uma parte da origem ainda resistia, o que se constata pelo uso do regionalismo "tchê" em paralelo com a língua portuguesa. Porém, quando perde aquilo que mais marca a sua identidade, o 'eu' sofre um processo de redimensionamento e transforma-se no 'outro'. O sentimento de estraneidade triunfa destruindo o único traço indentitário que ainda lhe era caro.

A intempestividade da língua estrangeira abala as parcas certezas do protagonista, fazendo-o afirmar que o inglês seria o "idioma que ostent[a] como segunda natureza, o idioma que [o] fará ser outro" (NOLL, 2002, p.66). Em decorrência disso, percebemos a negação tanto da língua materna quanto do lugar que ele dizia ocupar com orgulho, de escritor de língua portuguesa. Logo, a crise identitária avulta-se de tal forma que ele, para usufruir das glórias futuras, afirma o seguinte: "não sou mais brasileiro, frequento o mesmo quarto de Kennedy na sua juventude, eu também ainda sou um moço, [...] terei meus livros em qualquer livraria do Hemisfério Norte em todos os idiomas [...]" (NOLL, 2002, p.64).

O domínio do idioma estrangeiro é incapaz de gerar em João algum elo de pertencimento para com o novo território. Ao contrário, é o elemento causador da destruição do pouco que ainda lhe restava. Passada a euforia, a desilusão é tanta que o narrador-protagonista, em tom de lamento, afirma: "não quero mais ficar aqui nem um só dia, se é que vão me deixar sair, agora é tarde, só entendo o inglês" (NOLL, 2002, p.65). A estada em Bellagio perde o sentido e o brilho que um dia chegara a fascinar. O protagonista, acreditando que a Fundação não poderia esperar nada de um escritor desequilibrado que 
esqueceu a própria língua, solicita a rescisão do contrato e pede o reembolso de suas passagens. Sem ter concluído o romance que precisava entregar, ele regressa a Porto Alegre.

\section{4 (RE)FIXAR AS RAÍZES}

Insegurança, medo e esperança são os sentimentos que acompanham o protagonista durante a sua volta à terra natal. Seu futuro é uma incógnita, muitas são as dúvidas que permeiam suas divagações, tais como: Saberia encontrar seu apartamento? Teria, realmente, um apartamento? Onde trabalharia? Com quem conversaria em meio a uma grande população monoglota? Uma coisa é clara: o esquecimento da língua portuguesa não garantirá um retorno automático para a antiga identidade deixada para trás. Inclusive ele mesmo tem consciência de que, para resgatar alguns traços identitários e desenvolver novos laços de pertencimento, seria imprescindível um esforço de readaptação, de enfrentamento da situação:

Quando chegasse em Porto Alegre iria para um curso de português para estrangeiros no meu próprio torrão natal, [...]. Voltei-me para o outro lado e uma faísca saltou de mim: wake up, desperta, meu rapaz, enfrenta as coisas como são e vá em frente, vá pra sua casa se conseguir encontrá-la; se não, vá para um hotelzinho barato na Voluntários, não importa o endereço, importa, sim, que comeces a rever cada canto da cidade, tentando nesse método recuperar o português que com o calor úmido que faz deve estar escorrendo pelas paredes, muros, a sua língua-mãe padece com o seu extravio [...] (NOLL, 2002, p.82-83).

Se a identidade do protagonista sofreu um processo de transformação enquanto estava em solo estrangeiro - e, na volta para casa, ainda permanece em processo de mudança -, pode-se dizer o mesmo do seu "próprio torrão natal". Não foi apenas João que mudou, Porto Alegre também se alterou consubstancialmente. O narrador-protagonista, já no aeroporto de Malpensa, depara-se com uma legião de refugiados de países árabes que também tinham como destino a capital gaúcha. Com isso, a metrópole apresenta-se renovada e multicultural, aberta aos excluídos, receptiva àqueles que não têm mais nenhum outro lugar, capaz de acolher estrangeiros de todas as idades, os quais poderiam ali reconstruir as vidas devastadas em seus países de origem.

Nessa perspectiva, o olhar do personagem sobre a terra natal é redimensionado, assumindo uma polaridade positiva: "Eu estava num avião de refugiados, mas para mim pareciam mais peregrinos que encontrariam em Porto Alegre a terra prometida, o novo reino de Alá, ou de qualquer profeta menor, de alguma tribo" (NOLL, 2002, p.81). O território do regresso é o espaço da promessa de uma existência melhor, de uma vida com condições e perspectivas dignas para todos os deslocados, tanto que o protagonista afirma: "Porto Alegre, essa nova terra santa" (NOLL, 2002, p.84).

Embora tenha perdido o domínio do português, João experimenta uma sensação de bem-estar ao retornar, tanto que pronuncia em voz alta que "voltar para casa é o melhor da vida" (NOLL, 2002, p.81). A partir do momento em pisa em solo natal, a memória, aos poucos, vai retornando, e a primeira coisa que lembra é onde fica o seu apartamento. Ao abrir a porta da sua casa, ele percebe que o espaço não é mais o mesmo, pois se defronta com um homem que, de imediato, não reconhece, mas que posteriormente recorda ser Léo. Esse antigo companheiro vivera ali, durante os trânsitos do protagonista, com a filha Sarita, fruto de um relacionamento passageiro. Instantaneamente, a menina de cinco anos desperta uma intensa ternura no narrador-protagonista, que sente o instinto de proteger aquele pequeno ser. É a partir desse reencontro com o ex-companheiro e, sobretudo, do primeiro contato com a criança, que a língua materna começa a retornar para o escritor: 
[...] sou eu quem começo a entender de novo o português pela voz dessa criança que acabei de acalmar em castelhano, sou eu que sinto a mão pelos meus cabelos, é a mão de Léo, conheço-a de cor ainda, não, não esqueci como não esqueci de fato o português, [...] A minha memória parece mesmo que retorna aos poucos, aos frangalhos, [...] devagarinho vou ganhando a lembrança do meu português, a língua sai de mim em pedacinhos, escorrega de repente, apanho-a cansado, devolvo-a a minha boca, a palavra ecoa novamente, vibra mais alto agora [...] (NOLL, 2002, p.8687).

Em uma cidade reconfigurada, cosmopolita, um ponto de esperança brilha para João através da amálgama entre os antigos e novos vínculos de pertencimento. Além da língua que recupera, ele ainda tem o desejo de não mais ficar sozinho realizado em dose dupla, posto que passa a desfrutar da companhia diária de Léo e compartilhar a paternidade de Sarita. Há uma evidente tentativa de consolidação dos afetos por meio de uma nova composição da estrutura familiar, constituída por uma união homoafetiva. Tal desfecho de Berkeley em Bellagio, quase que idílico, afasta-se dos demais textos nollianos, os quais constantemente acenam para a impossibilidade de vinculação do sujeito a sociedade, bem como para o esfacelamento das instituições (principalmente as familiares), em que tudo sempre parece estar destinado ao fracasso. Essa possibilidade otimista em relação ao futuro que, assevera Gomes (2010), se associa com o sentido de localidade e "de reterritorialização, está associada ao resgate de resíduos utópicos, num momento em que as certezas da modernidade caíram por terra. Isso indica certa tendência da narrativa brasileira dos últimos anos, que busca ver o que não é inferno no meio do inferno".

A assunção da paternidade elimina o desejo de errância do protagonista, que, ao estar junto com a menina, reconhece: "não quero mais a volúpia de sair para as ruas à procura do que se nega ao menor laivo de busca" (NOLL, 2002, p.94). Não menos importante é o reatamento da relação com Léo, o qual finalmente preenchia a "viuvez nas rotinas" (NOLL, 2002, p.90) do protagonista. O novo relacionamento afetivo é tão positivo que faz com que o escritor volte a se dedicar a composição de seu livro. Assim, a fixação ao território original se dá, em especial, por meio do laço afetivo, o que é plenamente aceitável, considerando que "[...] a partir do momento em que os estrangeiros têm uma atitude ou uma paixão, eles fixam raízes. De forma provisória, com certeza, mas intensamente" (KRISTEVA, 1994, p.16).

\section{CONSIDERAÇÕES FINAIS}

Em Berkeley em Bellagio, os trânsitos realizados no exterior pelo protagonista, sedutores por se apresentarem como solução, mesmo que temporária, para a sua falta de perspectivas, simbolizam uma trégua à penúria social, econômica e afetiva experenciada por ele no Brasil. Todavia, nos territórios pelos quais transita, a adaptação nunca é plena, a identidade sempre está em descompasso, a ponto de João constatar que "Eu era outro em mim" (NOLL, 2002, p.82) e desejar regressar para seu país de origem. No retorno a Porto Alegre, o narrador-protagonista consegue desenvolver novos elos identitátios e recuperar o antigo vínculo de pertencimento, responsáveis por fixá-lo ao espaço.

No entanto, é necessário explicar que, apesar de João se restabelecer na terra natal, a posição de estrangeiro não é abandonada por completo. Voltar para a capital gaúcha, em momento algum, acarreta a retomada da velha identidade. Nesta narrativa de Noll, coerentemente com o universo líquidomoderno, a identidade não é um bem sólido, inabalável ou permanente; ao contrário, é algo provisório, inconstante, engendrado no presente. A própria memória estilhaçada do narrador, repleta de buracos ocasionados pela amnésia, faz com que seja impossível recompor o passado, pois o personagem nunca é o mesmo, assim como os espaços em transformação. Ele volta à cidade em que nasceu como um estrangeiro, afastado, inclusive, de sua língua-mãe, sendo recebido como hóspede em seu próprio 
apartamento. Hóspede porque acaba não se reapossando da propriedade, da mesma forma que, por meio de um acordo espontâneo e silencioso entre os dois homens, passa a dormir no sofá da sala.

Ocupar, na própria casa, um espaço e uma posição de passagem sugere a essência da aprendizagem que o protagonista adquiriu em seus trânsitos: de que o indivíduo é um estrangeiro para si mesmo, de que a identidade, antes de tudo, é a própria estranheza. E, parece ser justamente essa a lição que João pretende ensinar à Sarita, quando decide levá-la para conhecer o abrigo dos refugiados que vieram com ele, no avião. Ele o faz para que a filha encontre uma menina afegã que lhe chamara a atenção, explicando o seguinte: "esse povo que vamos conhecer espera um dia encontrar uma cozinha, quartos, uma sala como a nossa onde a chuva não alague, onde o tempero para a janta pode ficar sem fim no mesmo pote guardadinho nesse canto" (NOLL, 2002, p.102). Essa excursão é feita, talvez, como uma maneira de compreender, na transição do outro, a própria instabilidade, já que acontece no momento em que o narrador-protagonista encontra, supostamente, o equilíbrio e a estabilidade.

\section{REFERÊNCIAS}

BAUMAN, Zygmunt. Amor Líquido: sobre a fragilidade dos laços humanos. Trad. Carlos Alberto Medeiros. Rio de Janeiro: Jorge Zahar, 2004.

Confiança e medo na cidade. Trad. de Eliana Aguiar. Rio de Janeiro: Jorge Zahar, 2009.

Identidade: entrevista a Benedetto Vecchi. Trad. Carlos Alberto Medeiros. Rio de Janeiro: Jorge Zahar, 2005.

CURY, Maria Zilda Ferreira. Poéticas da precariedade. Estudos de literatura brasileira contemporânea. Brasília, n.41, p.33-46, 2013.

DALCASTAGNÈ, Regina. Literatura Brasileira Contemporânea: um território contestado. Vinhedo: Horizonte; Rio de Janeiro: UERJ, 2012.

GOMES, Renato Cordeiro. O nômade e a geografia (Lugar e não-lugar na narrativa urbana contemporânea). Revista Semear 10. In: Cátedra Padre António Vieira Estudos Portugueses, Rio de Janeiro, $\mathrm{n}^{\circ} 10$, 2010. Disponível em: <http://www.letras.pucrio.br/unidades\&nucleos/catedra/revista/10Sem_12.html>. Acesso em: 25 abr. 2016.

HALL, Stuart. A identidade cultural na pós-modernidade. Trad. Tomaz Tadeu da Silva e Guacira Lopes Louro. 8 ed. Rio de Janeiro: DP\&A, 2004.

KRISTEVA, Julia. Estrangeiros para nós mesmos. Trad. Maria Carlota Carvalho Gomes. Rio de Janeiro: Rocco, 1994.

NOLL, João Gilberto. Berkeley em Bellagio. Rio de Janeiro: Objetiva, 2002.

PORTO, Maria Bernadette Velloso. Circulações urbanas. In: BERND, Zilá (org.). Dicionário das mobilidades culturais: percursos americanos. Porto Alegre: Literalis, 2010, p.67-86.

SCHØLLHAMMER, Karl Erik. Fiç̧ão brasileira contemporânea. 2. ed. Rio de Janeiro: Civilização Brasileira, 2010. 